\title{
Brief communication: Spatial and temporal variations in surface snow chemistry along a traverse from coastal East Antarctica to the ice sheet summit (Dome A)
}

\author{
Guitao Shi ${ }^{1,2}$, Hongmei $\mathrm{Ma}^{2}$, Zhengyi Hu${ }^{2}$, Zhenlou Chen ${ }^{1}$, Chunlei $\mathrm{An}^{2}$, Su Jiang ${ }^{2}$, Yuansheng Li ${ }^{2}$, Tianming $\mathrm{Ma}^{2}$, \\ Jinhai Yu ${ }^{2}$, Danhe Wang ${ }^{1}$, Siyu Lu ${ }^{2}$, Bo Sun ${ }^{2}$, and Meredith G. Hastings ${ }^{3,4}$ \\ ${ }^{1}$ Key Laboratory of Geographic Information Science (Ministry of Education), School of Geographic Sciences and State Key \\ Laboratory of Estuarine and Coastal Research, East China Normal University, Shanghai 200241, China \\ ${ }^{2}$ Polar Research Institute of China, Shanghai 200062, China \\ ${ }^{3}$ Department of Earth, Environmental and Planetary Sciences, Brown University, Providence, Rhode Island 02912, USA \\ ${ }^{4}$ Institute at Brown for Environment and Society, Brown University, Providence, Rhode Island 02912, USA
}

Correspondence: Guitao Shi (gtshi@geo.ecnu.edu.cn)

Received: 2 September 2020 - Discussion started: 25 September 2020

Revised: 28 December 2020 - Accepted: 11 January 2021 - Published: 1 March 2021

\begin{abstract}
To better understand snow chemistry in different environments across the Antarctic ice sheet, we investigated snow ions on a traverse from the coast to Dome A. Results show that the non-sea-salt (nss) fractions of $\mathrm{K}^{+}, \mathrm{Mg}^{2+}$, and $\mathrm{Ca}^{2+}$ are mainly from terrestrial particle mass and $\mathrm{nssCl}^{-}$is associated with $\mathrm{HCl}$. Spatially, the non-sea-salt fractions of ions to the totals are higher in the interior areas than on the coast, and seasonally, the proportions are higher in summer than in winter. Negative $\mathrm{nssSO}_{4}^{2-}$ on the coast indicates sea salts from the sea ice, and marine biogenic emissions dominate snow $\mathrm{SO}_{4}^{2-}$ in interior areas throughout the year.
\end{abstract}

\section{Introduction}

Snow chemistry has been broadly investigated along traverses during the International Trans-Antarctic Scientific Expedition (ITASE), e.g., Dumont d'Urville Station (DDU) to Dome C, coast-interior traverse in Adélie Land, Syowa Station to Dome F, Terra Nova Bay to Dome C, 1990 ITASE, and US ITASE in West Antarctica (Legrand and Delmas, 1985; Qin et al., 1992; Mulvaney and Wolff, 1994; Proposito et al., 2002; Suzuki et al., 2002; Dixon et al., 2013), and Bertler et al. (2005) have comprehensively summarized the glaciochemical data across the ice sheet, most of which are for surface snow. Among the major ions, sea-salt-related ions (e.g., $\mathrm{Na}^{+}$and $\mathrm{Cl}^{-}$), in general, are the most abundant species and typically exhibit a clear spatial trend, with concentrations falling off sharply with distance from the coast.

Temporally, with varied sources and lifetimes, ions in snow often exhibit different seasonal variations; e.g., seasalt-related ions show high concentrations in winter, while elevated concentrations of $\mathrm{SO}_{4}^{2-}$ and $\mathrm{NO}_{3}^{-}$are frequently observed in summer (Neubauer and Heumann, 1988; Gragnani et al., 1998; Traversi et al., 2004; Shi et al., 2015). On annual to decadal timescales, ion concentrations in snow and ice tend to be associated with changes in transport from year to year (Severi et al., 2009; Weller et al., 2011), and thus largescale atmospheric and oceanic circulation in the Southern Hemisphere could potentially influence variations in snow and ice chemistry (Russell and McGregor, 2010; Weller et al., 2011; Mayewski et al., 2017).

Although investigations of snow chemistry have been carried out along several overland traverses, the investigation of snow chemistry under different environmental conditions and over time is needed, given that the Antarctic ice sheet itself and precipitation and deposition patterns and trends are changing. The Chinese inland Antarctic traverse from the coastal Zhongshan Station to the ice sheet summit (Dome A) covers a range of environments $(\sim 1250 \mathrm{~km})$; e.g., a high snow accumulation rate is present on the coast and in some interior areas and a low accumulation rate is observed on the Dome A plateau. Several investigations have been carried out 
to determine the concentrations of a few ionic species and trace elements on the traverse (e.g., Li et al., 2016; Du et al., 2019), but only limited snow chemistry data were previously available. Therefore, we used surface snow and snow pit samples collected during five Chinese inland Antarctic scientific expedition campaigns to determine the spatial and temporal variations and their controlling factors in a comprehensive set of ions $\left(\mathrm{Na}^{+}, \mathrm{NH}_{4}^{+}, \mathrm{K}^{+}, \mathrm{Mg}^{2+}, \mathrm{Ca}^{2+}, \mathrm{Cl}^{-}, \mathrm{NO}_{3}^{-}\right.$, and $\mathrm{SO}_{4}^{2-}$ ).

\section{Methods}

\subsection{Sample collection}

Snow samples were collected along the traverse from the coast to the ice sheet summit during five Chinese National Antarctic Research Expedition (CHINARE) campaigns (Fig. S1 in the Supplement). In January-February in the years 1999, 2011, 2013, 2015, and 2016, 107, 120, 125, 117 , and 125 surface snow samples, respectively, were collected on the traverse. In total, 594 snow samples were collected during the five seasons. For the snow sampling protocols, refer to Shi et al. (2018). It is noted that the collected surface $\sim 3 \mathrm{~cm}$ of snow represents different lengths of time at different locations, considering the wide range of snow accumulation rates on the traverse (Fig. 1a). At locations with a high snow accumulation rate on the coast, the upper $3 \mathrm{~cm}$ of snow may represent deposition from a few weeks or a single snowfall, while the surface $3 \mathrm{~cm}$ of snow could represent deposition over a few months on the Dome A plateau. Still, the information contained in the surface snow generally indicates summertime conditions, as the sampling took place during late January and February in each season.

In addition to surface snow, snow pits were sampled in three representative areas on the traverse: $\mathrm{P} 1$, located on the coast $\left(69.79^{\circ} \mathrm{S}, 76.49^{\circ} \mathrm{E} ; 46 \mathrm{~km}\right.$ from the coast), was sampled in December 2015; P2, located in the interior area $\left(76.42^{\circ} \mathrm{S}, 77.03^{\circ} \mathrm{E} ; 800 \mathrm{~km}\right.$ from the coast), was sampled in January 2016; and P3, located on the Dome A plateau $\left(80.42^{\circ} \mathrm{S}, 77.11^{\circ} \mathrm{E} ; 1256 \mathrm{~km}\right.$ from the coast), was sampled in January 2010 . Sites P1 and P2 are characterized by a high snow accumulation rate $\left(>100 \mathrm{~kg} \mathrm{~m}^{-2} \mathrm{a}^{-1}\right)$, while the snow accumulation rate at $\mathrm{P} 3$ is $\sim 25 \mathrm{~kg} \mathrm{~m}^{-2} \mathrm{a}^{-1}$. The depths of $\mathrm{P} 1, \mathrm{P} 2$, and $\mathrm{P} 3$ are 180,100 , and $150 \mathrm{~cm}$, respectively, with a respective sampling resolution of 5,3, and $1 \mathrm{~cm}$. Details on the snow pit sampling are described in Shi et al. (2015). All snow samples were transported and stored under freezing conditions $\left(\sim-20^{\circ} \mathrm{C}\right)$.

\subsection{Sample analysis}

In a class 100 clean room, about $5 \mathrm{~mL}$ of the melted sample was transferred to pre-cleaned $8 \mathrm{~mL}$ ion chromatography (IC) autosampler vials, and then the lid was tightly screwed on to the vials. The samples were analyzed by an ICS-3000 IC system (Dionex, USA) for the concentrations of ions $\left(\mathrm{Na}^{+}, \mathrm{NH}_{4}^{+}, \mathrm{K}^{+}, \mathrm{Mg}^{2+}, \mathrm{Ca}^{2+}, \mathrm{Cl}^{-}, \mathrm{NO}_{3}^{-}\right.$, and $\left.\mathrm{SO}_{4}^{2-}\right)$ in a class 1000 clean room. More details on ion determination are described in Shi et al. (2012). During sample analysis, replicate determinations $(n=5)$ were performed, and 1 relative standard deviation $(1 \sigma)$ for all eight ions was generally $<5 \%$.

In Antarctic snow, previous observations have suggested that concentrations of $\mathrm{H}^{+}$can be reasonably deduced from the ion-balance disequilibrium (Legrand and Delmas, 1985; Legrand, 1987):

$$
\begin{aligned}
{\left[\mathrm{H}^{+}\right] } & =\left[\mathrm{SO}_{4}^{2-}\right]+\left[\mathrm{NO}_{3}^{-}\right]+\left[\mathrm{Cl}^{-}\right]-\left[\mathrm{Na}^{+}\right]-\left[\mathrm{NH}_{4}^{+}\right] \\
& -\left[\mathrm{K}^{+}\right]-\left[\mathrm{Mg}^{2+}\right]-\left[\mathrm{Ca}^{2+}\right],
\end{aligned}
$$

where ion concentrations are in $\mu \mathrm{eq} \mathrm{L}^{-1}$. In addition, the nonsea-salt fractions of ions (nssX), including $\mathrm{nsSCl}^{-}, \mathrm{nssSO}_{4}^{2-}$, $\mathrm{nssK}^{+}, \mathrm{nssMg}^{2+}$, and $\mathrm{nssCa}^{2+}$, can be calculated from the following expression,

$[\mathrm{nssX}]=[\mathrm{X}]_{\text {snow }}-\left([\mathrm{X}] /\left[\mathrm{Na}^{+}\right]\right)_{\text {seawater }} \times\left[\mathrm{Na}^{+}\right]_{\text {snow }}$,

where $[\mathrm{X}]$ is the concentration of ion $\mathrm{X}$ and $[\mathrm{X}] /\left[\mathrm{Na}^{+}\right]$ratios in seawater are $1.17\left(\mathrm{Cl}^{-}\right), 0.12\left(\mathrm{SO}_{4}^{2-}\right), 0.022\left(\mathrm{~K}^{+}\right), 0.23$ $\left(\mathrm{Mg}^{2+}\right)$, and $0.044\left(\mathrm{Ca}^{2+}\right)$ (in $\mu$ eq $\left.\mathrm{L}^{-1}\right)$.

\section{Results}

\subsection{Ion variations in snow pits}

Clear seasonal cycles of $\mathrm{Na}^{+}$and $\mathrm{nssSO}_{4}^{2-}$ are present in $\mathrm{P} 1$ and $\mathrm{P} 2$, and thus the two pits can be well dated, spanning $\sim 3$ years (Fig. S2). In addition to $\mathrm{SO}_{4}^{2-}$ and $\mathrm{Na}^{+}$, the other species also show seasonal variations, especially in $\mathrm{P} 1$, where elevated levels of $\mathrm{NO}_{3}^{-}$and $\mathrm{NH}_{4}^{+}$are generally present in summer and the concentrations of $\mathrm{Cl}^{-}, \mathrm{K}^{+}, \mathrm{Mg}^{2+}$, and $\mathrm{Ca}^{2+}$ are high in winter. As for $\mathrm{nsSSO}_{4}^{2-}$ at $\mathrm{P} 3$, the very large signal at the depth of $\sim 120 \mathrm{~cm}$ is most likely the fallout from the massive eruption of Pinatubo in 1991 (Fig. S2), based upon previous observations at Dome A (e.g., Hou et al., 2007). It is noted that only elevated $\mathrm{SO}_{4}^{2-}$ concentrations are present during this period, possibly suggesting that Pinatubo volcanic emissions contribute less to the ion budgets other than to $\mathrm{SO}_{4}^{2-}$ at Dome A.

In terms of the non-sea-salt fractions, $\mathrm{nssCl}^{-}$is lower at P1 $\left(0.25 \pm 0.28 \mu \mathrm{eq} \mathrm{L}^{-1}\right)$ than at the inland sites P2 and P3 $\left(0.42 \pm 0.18\right.$ and $0.58 \pm 0.34 \mu \mathrm{eqL} \mathrm{L}^{-1}$, respectively), while the concentrations of $\mathrm{nssK}^{+}, \mathrm{nssMg}^{2+}$, and $\mathrm{nssCa}^{2+}$ generally show a similar spatial pattern. In general, $\mathrm{nssCl}^{-}, \mathrm{nssK}^{+}$, $\mathrm{nssMg}^{2+}$, and $\mathrm{nssCa}^{2+}$ in snow pits do not show clear seasonal cycles. 

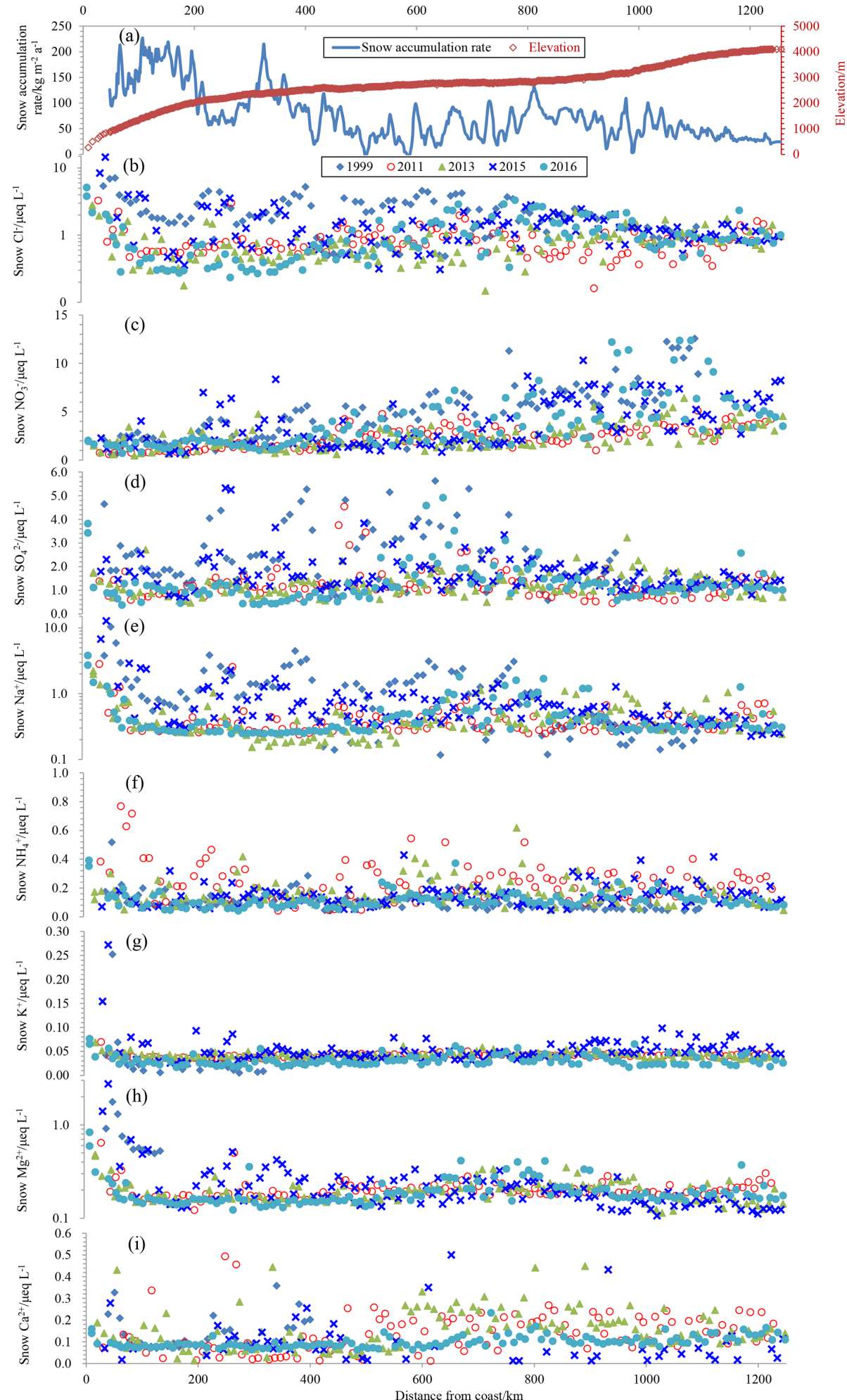

Figure 1. Annual snow accumulation rate and elevation (a) and ion concentrations in surface snow collected during five seasons (b-i). Annual snow accumulation rate is obtained from field bamboo stick measurements, updated to 2016 from Ding et al. (2011). The closed diamond, open circle, closed triangle, cross, and closed circle denote ion concentrations in the years 1999, 2011, 2013, 2015, and 2016, respectively. Note that a base-10 log scale is used for the $y$ axis of $\mathrm{Cl}^{-}$(b), $\mathrm{Na}^{+}$(e), and $\mathrm{Mg}^{2+}$ (h). 


\subsection{Ion concentrations in surface snow}

Concentrations of ions in surface snow are shown in Fig. 1, and the values generally fall within the reported ranges of the ITASE program sampling (Bertler et al., 2005). Spatially, $\mathrm{Cl}^{-}, \mathrm{Na}^{+}, \mathrm{K}^{+}$, and $\mathrm{Mg}^{2+}$ show very high concentrations within the narrow coastal region and decrease sharply further inland, with minimum values on the Dome A plateau ( $>\sim 1000 \mathrm{~km}$ from the coast). It is noted that some samples on the coast also show elevated $\mathrm{Ca}^{2+}$ concentrations. The high ion concentrations near the coast may be associated with the strong marine air mass intrusions (Hara et al., 2014). $\mathrm{NO}_{3}^{-}$shows an opposite spatial trend, with increasing values towards the inland. As for $\mathrm{SO}_{4}^{2-}$ (and $\mathrm{nssSO}_{4}^{2-}$ ), $\mathrm{NH}_{4}^{+}$, and $\mathrm{Ca}^{2+}$, no clear spatial trend was found.

Among the ions in surface snow, the most abundant species is $\mathrm{H}^{+}$, accounting for $30 \%-40 \%$ of the total ions, followed by $\mathrm{NO}_{3}^{-}, \mathrm{SO}_{4}^{2-}$, and $\mathrm{Cl}^{-}$. In general, $\mathrm{NH}_{4}^{+}, \mathrm{K}^{+}$, $\mathrm{Mg}^{2+}$, and $\mathrm{Ca}^{2+}$ are the smallest components of the ionic composition, with the four cations summing to $(6.0 \pm 3.4) \%$ of the total (Fig. S3).

\section{Discussions}

\subsection{Non-sea-salt fractions of ions in surface snow}

Correlation plots of ions versus $\mathrm{Na}^{+}$in surface snow are shown in Fig. 2. On the coast, most of the $\mathrm{Cl}^{-} / \mathrm{Na}^{+}$data are distributed close to the seawater dilution line (Fig. 2a), while most of the plots in the interior areas are above the seawater line, suggesting an enrichment of $\mathrm{Cl}^{-}$. The $\mathrm{nssCl}^{-}$accounted for $(39 \pm 24) \%$ of $\mathrm{Cl}^{-}$on the traverse, with higher values in the interior areas. The elevated fractions of $\mathrm{nssCl}^{-}$are likely associated with the "secondary" $\mathrm{HCl}$ which is produced by the reactions between sea salts and acids (e.g., $\mathrm{HNO}_{3}$ and $\mathrm{H}_{2} \mathrm{SO}_{4}$ ) (Finlayson-Pitts, 2003).

$\mathrm{Mg}^{2+}$ is irreversibly deposited into the snow, and the fraction of $\mathrm{nssMg}^{2+}$, on average, represents $(44 \pm 19) \%$ of $\mathrm{Mg}^{2+}$ in snow, with lower (higher) values on the coast (plateau) (Fig. 2d). The enrichment of $\mathrm{Mg}^{2+}$ has not been observed in sea salt particles produced by bubble bursting (Keene et al., 2007), and thus enriched $\mathrm{Mg}^{2+}$ in the snow is unlikely to be associated with sea salt spray. In the atmosphere, sea salt aerosols can be modified at low temperatures via the formation of mirabilite, thus leading to an elevated ratio of $\mathrm{Mg}^{2+} / \mathrm{Na}^{+}$if mirabilite precipitates from the aerosols. However, the solid-liquid separation of mirabilite in the aerosol droplet was not observed in the experiments (Wagenbach et al., 1998). Thus, the enrichment of $\mathrm{Mg}^{2+}$ in surface snow is unlikely to be associated with sea salt fractionation. Although it is proposed that $\mathrm{Mg}^{2+}$ separation in sea salts can occur in surface snow due to the re-freezing process on surface snow (i.e., the quasi-liquid layers on the crystal surface can act like seawater freezing; Hara et al., 2014), our mea- surement of $\mathrm{Mg}^{2+}$ in bulk snow is unlikely to support this process responsible for $\mathrm{Mg}^{2+}$ enrichment. A previous observation conducted near this traverse showed a moderate correlation of $\mathrm{Mg}^{2+}$ with the element $\mathrm{Al}$ in the surface snowpack $(r=0.53 ; p<0.05)$, indicating a contribution of continental dust (Khodzher et al., 2014). Thus, the most plausible interpretation of $\mathrm{nssMg}^{2+}$ is the contribution of terrestrial aerosols. Similarly to $\mathrm{Mg}^{2+}$, most of $\mathrm{K}^{+} / \mathrm{Na}^{+}$data points are close to the seawater dilution line on the coast, suggesting a primary contribution of sea salt spray (Fig. 2c). Enriched $\mathrm{K}^{+}$is ubiquitous in interior areas, possibly associated with mineral transport and combustion emissions in the Southern Hemisphere (Virkkula et al., 2006; Hara et al., 2013). Note that all sampling sites are at least several tens of kilometers away from the coast, so the contribution of biological activity to snow $\mathrm{K}^{+}$would be rather minor (Rankin and Wolff, 2000). A lack of correlation between $\mathrm{K}^{+}$(or $\mathrm{nssK}^{+}$) and refractory black carbon (rBC; unpublished data; Fig. S4), which mainly represents the biomass burning emissions in the Southern Hemisphere (Sigl et al., 2016), suggests that $\mathrm{K}^{+}$in surface snow is unlikely dominated by biomass burning emissions.

The fraction of $\mathrm{nssCa}^{2+}$, on average, accounts for $(73 \pm$ 26) $\%$ of total $\mathrm{Ca}^{2+}$ in surface snow, with high percentages in the interior areas. In Antarctica, snow nssCa ${ }^{2+}$ was thought to be mainly associated with terrestrial inputs, possibly from both South America and Australia (Bertler et al., 2005; Wolff et al., 2010; Du et al., 2018). The nssSO ${ }_{4}^{2-}$ represents $(94 \pm 5) \%$ of total $\mathrm{SO}_{4}^{2-}$ in surface snow, with lower (higher) proportions on the coast (plateau) (Fig. 2b), suggesting a dominant role of marine bioactivities. Differently from the coarse-sea-salt aerosols, $\mathrm{nssSO}_{4}^{2-}$ originating from marine biogenic production of dimethylsulfide can form fine aerosol particles in the atmosphere (Legrand et al., 2017a), resulting in a long atmospheric residence time ( $>10 \mathrm{~d}$ to weeks) and consequently efficient transport (Bondietti and Papastefanou, 1993; Hara et al., 2014). This can help explain the elevated deposition flux of $\mathrm{nssSO}_{4}^{2-}$ frequently found at inland Antarctic sites, e.g., site P2 (discussed below).

\subsection{Non-sea-salt fractions and fluxes of ions in snow pits}

At P1, the slope values of the linear regression between $\mathrm{Na}^{+}$ and the four ions are close to those of seawater (Fig. 3), suggesting a dominant source of sea salt aerosols. The proportions of the non-sea-salt fractions of $\mathrm{K}^{+}, \mathrm{Mg}^{2+}$, and $\mathrm{Ca}^{2+}$ to the ions in snow are much lower in winter than in summer, as a result of the high sea salt inputs in winter. Negative $\mathrm{nssCl}^{-}$ is present in summer snow, indicating the modification to sea salts (i.e., formation of mirabilite in the atmosphere) in summer when the acid levels (e.g., $\mathrm{HNO}_{3}$ ) are relatively high (Savarino et al., 2007). Some winter snow samples featured negative $\mathrm{nssSO}_{4}^{2-}$, i.e., an $\mathrm{SO}_{4}^{2-} / \mathrm{Na}^{+}$ratio below the value of seawater (Fig. S2), suggesting sea salt aerosols originating from the sea ice (Marion et al., 1999). In the winter snow, if 

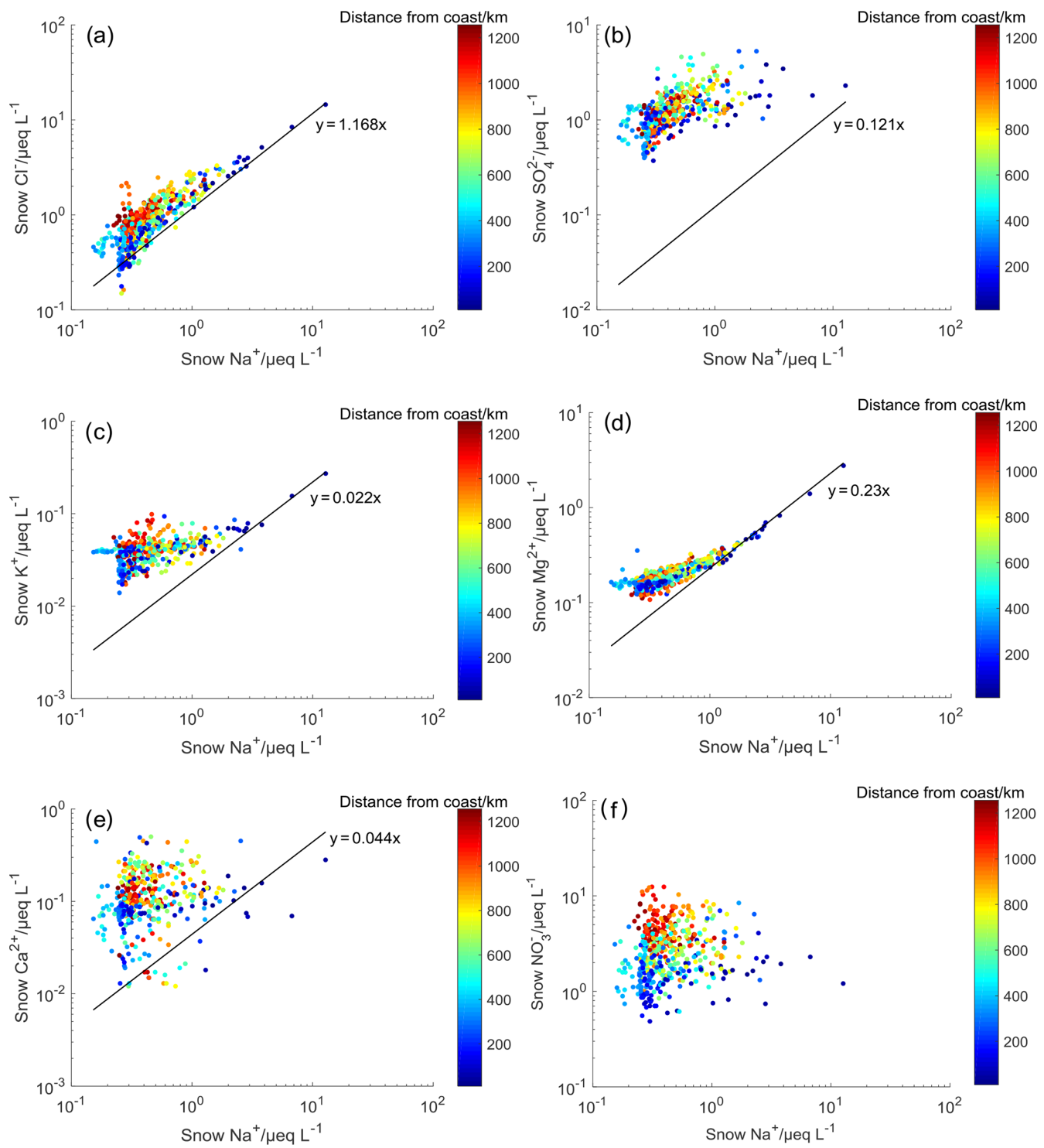

Figure 2. Correlation plots of $\mathrm{Cl}^{-}, \mathrm{SO}_{4}^{2-}, \mathrm{K}^{+}, \mathrm{Mg}^{2+}, \mathrm{Ca}^{2+}$, and $\mathrm{NO}_{3}^{-}$versus $\mathrm{Na}^{+}$in surface snow. The solid black line represents the seawater dilution line, with slopes of typical ions versus $\mathrm{Na}^{+}$ratios in seawater (in $\mu \mathrm{eq} \mathrm{L}^{-1}$ ). The concentration of $\mathrm{NO}_{3}^{-}$in seawater is too variable among the seas, and a representative ratio of $\mathrm{NO}_{3}^{-} / \mathrm{Na}^{+}$cannot be presented. Note that a base- 10 log scale is used for ion concentrations.

all $\mathrm{SO}_{4}^{2-}$ is from sea salt aerosols, $\mathrm{nssSO}_{4}^{2-}$ is expected to be lower than or close to zero. However, 13 out of the 17 samples classified as winter snow at P1 were characterized by positive $\mathrm{nsSO}_{4}^{2-}$, suggesting a significant contribution from marine biogenic emissions. It is interesting that $\mathrm{nsSO}_{4}^{2-}$ has a strong negative correlation with $\mathrm{Na}^{+}$in winter $(r=0.82$; $p<0.001$ ), raising two potential cases: (1) stronger winds transport more sea salt aerosols to P1 which feature depleted $\mathrm{SO}_{4}^{2-}$ from sea ice, thereby resulting in low concentrations of $\mathrm{nsSO}_{4}^{2-}$ and assuming a stable $\mathrm{SO}_{4}^{2-}$ input flux from marine biogenic emissions, and/or (2) with a larger extent of sea ice and strong transport, a large sea salt flux would still occur but carry less $\mathrm{nssSO}_{4}^{2-}$ from marine biogenic emissions due to the longer transport distance (Wolff et al., 2006, and references therein). If case (2) dominated $\mathrm{nssSO}_{4}^{2-}$ variations in the winter snow, lower nssSO ${ }_{4}^{2-}$ would be expected at the end than at the beginning of winter when a sea ice coverage minimum is present. The observation at $\mathrm{P} 1$, however, does not support this expected seasonal trend (Fig. S2). It is most likely, then, that sea salt aerosol inputs instead of marine biogenic emissions dominate $\mathrm{nssSO}_{4}^{2-}$ variations in winter snow.

The patterns of relationships between ions and $\mathrm{Na}^{+}$at $\mathrm{P} 2$ are similar to those of $\mathrm{P} 1$ except for $\mathrm{Ca}^{2+}$ (Fig. 3). Non-sea- 

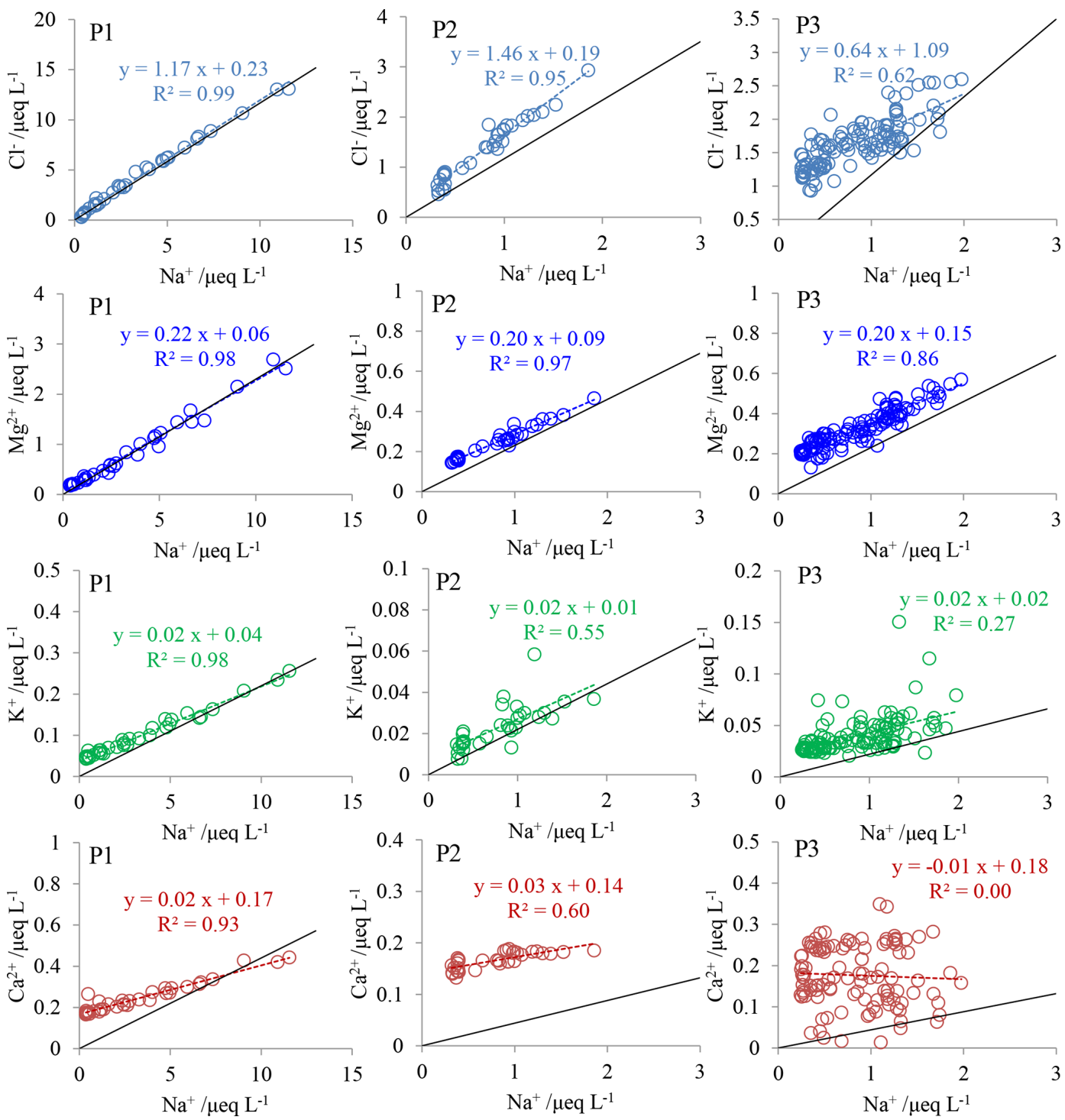

Figure 3. Relationships between $\mathrm{Na}^{+}$and $\mathrm{Cl}^{-}, \mathrm{K}^{+}, \mathrm{Mg}^{2+}$, and $\mathrm{Ca}^{2+}$ in the three snow pits (P1, P2, and P3). Also shown are the linear regressions between them (dashed line), with all of the linear correlations significant at $p<0.001$ except $\mathrm{Ca}^{2+} / \mathrm{Na}^{+}$at $\mathrm{P} 3$. The solid black line represents the seawater dilution line. Note that the data of the bottom $\sim 30 \mathrm{~cm}$ layer of P3 were excluded in the plots, since they represent a snow layer clearly impacted by volcanic (Pinatubo) eruption emissions.

salt fractions of $\mathrm{Ca}^{2+}$ account for (79 \pm 9$) \%$ of the total, suggesting a dominant role of the terrestrial source. It is noted that $\mathrm{Ca}^{2+}$ remains relatively constant with increasing $\mathrm{Na}^{+}$ (Fig. 3), possibly suggesting insignificant seasonal variations in terrestrial dust inputs. The fractions of $\mathrm{nsSSO}_{4}^{2-}$ to $\mathrm{SO}_{4}^{2-}$ in summer and winter snow are $(94 \pm 4) \%$ and $(88 \pm 4) \%$, respectively, suggesting a dominant role of marine biogenic emissions, differently from those at P1. Previous investigations proposed that sea salt aerosols emitted from sea ice are an important contribution to the sea salt budget in central Antarctica in winter (Legrand et al., 2016, 2017b). Here, the high $\mathrm{nsSSO}_{4}^{2-}$ concentrations indicate that marine emissions could also be an important source of ions in winter.
At P3, $\mathrm{Cl}^{-}, \mathrm{K}^{+}$, and $\mathrm{Mg}^{2+}$ are also correlated well with $\mathrm{Na}^{+}$(Fig. 3). The non-sea-salt fractions of $\mathrm{Cl}^{-}$make up $(38 \pm 24) \%$ of the total, similarly to those at P2, indicating the importance of $\mathrm{HCl}$ deposition, and consequently result in $\mathrm{Cl}^{-}$not being a quantitative indicator of sea salts in the interior areas. The $\mathrm{nsSSO}_{4}^{2-}$ at $\mathrm{P} 3$ accounts for $(95 \pm 2) \%$ of $\mathrm{SO}_{4}^{2-}$. Together with the observations at $\mathrm{P} 2$, it can be inferred that $\mathrm{SO}_{4}^{2-}$ in the interior areas is dominated by marine biogenic emissions throughout the year, generally in line with the observation at Dome C (Udisti et al., 2012).

Ion fluxes in the three snow pits can be determined by multiplying the concentrations by the snow accumulation rate, and the highest fluxes of ions except for $\mathrm{NO}_{3}^{-}$were gener- 
ally present at $\mathrm{P} 1$, followed by $\mathrm{P} 2$ and $\mathrm{P} 3$ (Fig. S5). It is noted that $\mathrm{nsSSO}_{4}^{2-}$ fluxes at $\mathrm{P} 1\left(99.4 \pm 46.7 \mu \mathrm{eq} \mathrm{m} \mathrm{m}^{-2} \mathrm{a}^{-1}\right)$ and $\mathrm{P} 2\left(109.2 \pm 21.6 \mu \mathrm{eq} \mathrm{m}^{-2} \mathrm{a}^{-1}\right)$ are comparable, although $\mathrm{P} 1$ is located on the coast and P2 is located further inland $\left(\sim 800 \mathrm{~km}\right.$ from the coast). In addition, the ratio of $\mathrm{nsSSO}_{4}^{2-}$ flux at $\mathrm{P} 1$ to that at $\mathrm{P} 3$ is 2.2 , the lowest among the ratios for the observed ions $(17.2,7.5,26.7,8.5,17.4,17.0$, and 10.0 for $\mathrm{Cl}^{-}, \mathrm{NO}_{3}^{-}, \mathrm{Na}^{+}, \mathrm{NH}_{4}^{+}, \mathrm{K}^{+}, \mathrm{Mg}^{2+}$, and $\mathrm{Ca}^{2+}$, respectively), suggesting more efficient transport of $\mathrm{nssSO}_{4}^{2-}$. In other words, atmospheric $\mathrm{nssSO}_{4}^{2-}$ from the open ocean can be efficiently transported to at least as far inland as $\sim 800 \mathrm{~km}$ from the coast ( $\sim 2800 \mathrm{~m}$ above sea level; site P2).

\section{Conclusions}

Snow chemistry on a traverse from the coastal Zhongshan Station to Dome A was investigated. It is shown that the nonsea-salt fractions of $\mathrm{K}^{+}, \mathrm{Mg}^{2+}$, and $\mathrm{Ca}^{2+}$ are mainly associated with terrestrial particle mass, while $\mathrm{nssCl}^{-}$is linked to the deposition of $\mathrm{HCl}$. Spatially, the proportions of non-seasalt fractions of ions to the totals are higher in the interior areas than on the coast, and seasonally, the proportions are generally higher in summer than in winter, due to the high sea salt inputs during wintertime. Negative $\mathrm{nsSO}_{4}^{2-}$ observed on the coast indicates sea salts mainly originating from the sea ice in winter, while positive $\mathrm{nssSO}_{4}^{2-}$ is present throughout the year in the interior areas, suggesting the dominating role of marine biogenic emissions. The $\mathrm{nssSO}_{4}^{2-}$ can be transported efficiently to at least as far inland as the $\sim 2800 \mathrm{~m}$ contour line.

Data availability. This dataset, chemical data on ion concentrations in snow on the traverse from the coast (Zhongshan Station) to Dome A, is available from the Chinese National Arctic and Antarctic Data Center: https://doi.org/10.11856/SNS.D.2021.003.v0 (Shi, 2021).

Supplement. The supplement related to this article is available online at: https://doi.org/10.5194/tc-15-1087-2021-supplement.

Author contributions. GS, ZC, YL, and BS designed the experiments, and GS, HM, ZH, CA, SJ, TM, JY, DW, and SL carried them out. GS and MGH prepared the manuscript with contributions from all co-authors.

Competing interests. The authors declare that they have no conflict of interest.

Acknowledgements. This research was supported by the National Science Foundation of China (grant nos. 41922046 and
41576190 to Guitao Shi, grant no. 41876225 to Hongmei Ma) and the National Key Research and Development Program of China (grant no. 2016YFA0302204 to Guitao Shi and grant no. 2019YFC1509102 to Bo Sun). The authors are grateful to the CHINARE inland members for logistic support and assistance.

Financial support. This research has been supported by the National Natural Science Foundation of China (grant nos. 41922046, 41876225, and 41576190), and the National Key Research and Development Program of China (grant nos. 2016YFA0302204 and 2019YFC1509102).

Review statement. This paper was edited by Joel Savarino and reviewed by Legrand Michel and one anonymous referee.

\section{References}

Bertler, N., Mayewski, P. A., Aristarain, A., Barrett, P., Becagli, S., Bernardo, R., Bo, S., Xiao, C., Curran, M., and Qin, D.: Snow chemistry across Antarctica, Ann. Glaciol., 41, 167-179, 2005.

Bondietti, E. A. and Papastefanou, C.: Estimates of residence times of sulfate aerosols in ambient air, Sci. Total Environ., 136, 25-31, https://doi.org/10.1016/0048-9697(93)90294-G, 1993.

Ding, M., Xiao, C., Li, Y., Ren, J., Hou, S., Jin, B., and Sun, B.: Spatial variability of surface mass balance along a traverse route from Zhongshan station to Dome A, Antarctica, J. Glaciol., 57, 658-666, 2011.

Dixon, D. A., Mayewski, P. A., Korotkikh, E., Sneed, S. B., Handley, M. J., Introne, D. S., and Scambos, T. A.: Variations in snow and firn chemistry along US ITASE traverses and the effect of surface glazing, The Cryosphere, 7, 515-535, https://doi.org/10.5194/tc-7-515-2013, 2013.

Du, Z., Xiao, C., Ding, M., and Li, C.: Identification of multiple natural and anthropogenic sources of dust in snow from Zhongshan Station to Dome A, East Antarctica, J. Glaciol., 64, 855-865, https://doi.org/10.1017/jog.2018.72, 2018.

Du, Z., Xiao, C., Handley, M. J., Mayewski, P. A., Li, C., Liu, S., $\mathrm{Ma}, \mathrm{X}$., and Yang, J.: Fe variation characteristics and sources in snow samples along a traverse from Zhongshan Station to Dome A, East Antarctica, Sci. Total Environ., 675, 380-389, https://doi.org/10.1016/j.scitotenv.2019.04.139, 2019.

Finlayson-Pitts, B. J.: The tropospheric chemistry of sea salt: a molecular-level view of the chemistry of $\mathrm{NaCl}$ and $\mathrm{NaBr}$, Chem. Rev., 103, 4801-4822, 2003.

Gragnani, R., Smiraglia, C., Stenni, B., and Torcini, S.: Chemical and isotopic profiles from snow pits and shallow firn cores on Campbell Glacier, northern Victoria Land, Antarctica, Ann. Glaciol., 27, 679-684, 1998.

Hara, K., Osada, K., and Yamanouchi, T.: Tethered balloonborne aerosol measurements: seasonal and vertical variations of aerosol constituents over Syowa Station, Antarctica, Atmos. Chem. Phys., 13, 9119-9139, https://doi.org/10.5194/acp-139119-2013, 2013.

Hara, K., Nakazawa, F., Fujita, S., Fukui, K., Enomoto, H., and Sugiyama, S.: Horizontal distributions of aerosol constituents and their mixing states in Antarctica during the 
JASE traverse, Atmos. Chem. Phys., 14, 10211-10230, https://doi.org/10.5194/acp-14-10211-2014, 2014.

Hou, S., Li, Y., Xiao, C., and Ren, J.: Recent accumulation rate at Dome A, Antarctica, Chin. Sci. Bull., 52, 428-431, 2007.

Keene, W. C., Maring, H., Maben, J. R., Kieber, D. J., Pszenny, A. A., Dahl, E. E., Izaguirre, M. A., Davis, A. J., Long, M. S., and Zhou, X.: Chemical and physical characteristics of nascent aerosols produced by bursting bubbles at a model air-sea interface, J. Geophys. Res., 112, D21202, https://doi.org/10.1029/2007JD008464, 2007.

Khodzher, T. V., Golobokova, L. P., Osipov, E. Yu., Shibaev, Yu. A., Lipenkov, V. Ya., Osipova, O. P., and Petit, J. R.: Spatialtemporal dynamics of chemical composition of surface snow in East Antarctica along the Progress station-Vostok station transect, The Cryosphere, 8, 931-939, https://doi.org/10.5194/tc-8931-2014, 2014.

Legrand, M.: Chemistry of Antarctic snow and ice, J. de Phys., 48, 77-86, 1987.

Legrand, M. and Delmas, R. J.: Spatial and temporal variations of snow chemistry in Terre Adélie (East Antarctica), Ann. Glaciol., 7, 20-25, 1985.

Legrand, M., Yang, X., Preunkert, S., and Theys, N.: Year-round records of sea salt, gaseous, and particulate inorganic bromine in the atmospheric boundary layer at coastal (Dumont d'Urville) and central (Concordia) East Antarctic sites, J. Geophys. Res., 121, 2015JD024066, https://doi.org/10.1002/2015JD024066, 2016.

Legrand, M., Preunkert, S., Weller, R., Zipf, L., Elsässer, C., Merchel, S., Rugel, G., and Wagenbach, D.: Year-round record of bulk and size-segregated aerosol composition in central Antarctica (Concordia site) - Part 2: Biogenic sulfur (sulfate and methanesulfonate) aerosol, Atmos. Chem. Phys., 17, 1405514073, https://doi.org/10.5194/acp-17-14055-2017, 2017a.

Legrand, M., Preunkert, S., Wolff, E., Weller, R., Jourdain, B., and Wagenbach, D.: Year-round records of bulk and sizesegregated aerosol composition in central Antarctica (Concordia site) - Part 1: Fractionation of sea-salt particles, Atmos. Chem. Phys., 17, 14039-14054, https://doi.org/10.5194/acp-17-140392017, 2017b.

Li, C., Xiao, C., Shi, G., Ding, M., Qin, D., and Ren, J.: Spatial and temporal variability of marine-origin matter along a transect from Zhongshan Station to Dome A, Eastern Antarctica, J. Environ. Sci., 46, 190-202, https://doi.org/10.1016/j.jes.2015.07.011, 2016.

Marion, G., Farren, R., and Komrowski, A.: Alternative pathways for seawater freezing, Cold Reg. Sci. Technol., 29, 259-266, 1999.

Mayewski, P. A., Carleton, A. M., Birkel, S. D., Dixon, D., Kurbatov, A. V., Korotkikh, E., McConnell, J., Curran, M., Cole-Dai, J., Jiang, S., Plummer, C., Vance, T., Maasch, K. A., Sneed, S. B., and Handley, M.: Ice core and climate reanalysis analogs to predict Antarctic and Southern Hemisphere climate changes, Quaternary Sci. Rev., 155, 50-66, https://doi.org/10.1016/j.quascirev.2016.11.017, 2017.

Mulvaney, R. and Wolff, E.: Spatial variability of the major chemistry of the Antarctic ice sheet, Ann. Glaciol., 20, 440-447, 1994.

Neubauer, J. and Heumann, K. G.: Nitrate trace determinations in snow and firn core samples of ice shelves at the Weddell Sea, Antarctica, Atmos. Environ., 22, 537-545, 1988.
Proposito, M., Becagli, S., Castellano, E., Flora, O., Genoni, L., Gragnani, R., Stenni, B., Traversi, R., Udisti, R., and Frezzotti, M.: Chemical and isotopic snow variability along the 1998 ITASE traverse from Terra Nova Bay to Dome C, East Antarctica, Ann. Glaciol., 35, 187-194, 2002.

Qin, D., Zeller, E. J., and Dreschhoff, G. A.: The distribution of nitrate content in the surface snow of the Antarctic Ice Sheet along the route of the 1990 International Trans-Antarctica Expedition, J. Geophys. Res., 97, 6277-6284, 1992.

Rankin, A. M. and Wolff, E. W.: Ammonium and potassium in snow around an emperor penguin colony, Antarct. Sci., 12, 154-159, https://doi.org/10.1017/S0954102000000201, 2000.

Russell, A. and McGregor, G. R.: Southern hemisphere atmospheric circulation: impacts on Antarctic climate and reconstructions from Antarctic ice core data, Climatic Change, 99, 155-192, 2010.

Savarino, J., Kaiser, J., Morin, S., Sigman, D. M., and Thiemens, M. H.: Nitrogen and oxygen isotopic constraints on the origin of atmospheric nitrate in coastal Antarctica, Atmos. Chem. Phys., 7, 1925-1945, https://doi.org/10.5194/acp-7-1925-2007, 2007.

Severi, M., Becagli, S., Castellano, E., Morganti, A., Traversi, R., and Udisti, R.: Thirty years of snow deposition at Talos Dome (Northern Victoria Land, East Antarctica): Chemical profiles and climatic implications, Microchem. J., 92, 15-20, https://doi.org/10.1016/j.microc.2008.08.004, 2009.

Shi, G.: Data set to: Surface snow chemistry data along a traverse from coastal East Antarctica to the ice sheet summit, Dome A, Data-sharing Platform of Polar Science, National Arctic and Antarctic Data Center, https://doi.org/10.11856/SNS.D.2021.003.v0, 2021.

Shi, G., Li, Y., Jiang, S., An, C., Ma, H., Sun, B., and Wang, Y.: Large-scale spatial variability of major ions in the atmospheric wet deposition along the China Antarctica transect $\left(31^{\circ} \mathrm{N}-69^{\circ} \mathrm{S}\right)$, Tellus B, 64, 17134, https://doi.org/10.3402/tellusb.v64i0.17134, 2012.

Shi, G., Buffen, A. M., Hastings, M. G., Li, C., Ma, H., Li, Y., Sun, B., An, C., and Jiang, S.: Investigation of post-depositional processing of nitrate in East Antarctic snow: isotopic constraints on photolytic loss, re-oxidation, and source inputs, Atmos. Chem. Phys., 15, 9435-9453, https://doi.org/10.5194/acp15-9435-2015, 2015.

Shi, G., Buffen, A. M., Ma, H., Hu, Z., Sun, B., Li, C., Yu, J., Ma, T., An, C., Jiang, S., Li, Y., and Hastings, M. G.: Distinguishing summertime atmospheric production of nitrate across the East Antarctic Ice Sheet, Geochim. Cosmochim. Ac., 231, 1-14, https://doi.org/10.1016/j.gca.2018.03.025, 2018.

Sigl, M., Fudge, T. J., Winstrup, M., Cole-Dai, J., Ferris, D., McConnell, J. R., Taylor, K. C., Welten, K. C., Woodruff, T. E., Adolphi, F., Bisiaux, M., Brook, E. J., Buizert, C., Caffee, M. W., Dunbar, N. W., Edwards, R., Geng, L., Iverson, N., Koffman, B., Layman, L., Maselli, O. J., McGwire, K., Muscheler, R., Nishiizumi, K., Pasteris, D. R., Rhodes, R. H., and Sowers, T. A.: The WAIS Divide deep ice core WD2014 chronology Part 2: Annual-layer counting (0-31 ka BP), Clim. Past, 12, 769786, https://doi.org/10.5194/cp-12-769-2016, 2016.

Suzuki, T., Iizuka, Y., Matsuoka, K., Furukawa, T., Kamiyama, K., and Watanabe, O.: Distribution of sea salt components in snow cover along the traverse route from the coast to Dome Fuji station 
$1000 \mathrm{~km}$ inland at east Dronning Maud Land, Antarctica, Tellus B, 54, 407-411, 2002.

Traversi, R., Becagli, S., Castellano, E., Largiuni, O., Migliori, A., Severi, M., Frezzotti, M., and Udisti, R.: Spatial and temporal distribution of environmental markers from Coastal to Plateau areas in Antarctica by firn core chemical analysis, Int. J. Environ. Anal. Chem., 84, 457-470, https://doi.org/10.1080/03067310310001640393, 2004.

Udisti, R., Dayan, U., Becagli, S., Busetto, M., Frosini, D., Legrand, M., Lucarelli, F., Preunkert, S., Severi, M., and Traversi, R.: Sea spray aerosol in central Antarctica. Present atmospheric behaviour and implications for paleoclimatic reconstructions, Atmos. Environ., 52, 109-120, https://doi.org/10.1016/j.atmosenv.2011.10.018, 2012.

Virkkula, A., Teinilä, K., Hillamo, R., Kerminen, V.-M., Saarikoski, S., Aurela, M., Viidanoja, J., Paatero, J., Koponen, I. K., and Kulmala, M.: Chemical composition of boundary layer aerosol over the Atlantic Ocean and at an Antarctic site, Atmos. Chem. Phys., 6, 3407-3421, https://doi.org/10.5194/acp-6-3407-2006, 2006.

Wagenbach, D., Ducroz, F., Mulvaney, R., Keck, L., Minikin, A., Legrand, M., Hall, J. S., and Wolff, E. W.: Sea-salt aerosol in coastal Antarctic regions, J. Geophys. Res., 103, 10961-10974, 1998.
Weller, R., Wagenbach, D., Legrand, M., Elsässer, C., Tian-kunze, X., and Königlanglo, G.: Continuous 25-yr aerosol records at coastal Antarctica: inter-annual variability of ionic compounds and links to climate indices, Tellus B, 63, 901-919, https://doi.org/10.1111/j.1600-0889.2011.00542.x, 2011.

Wolff, E. W., Fischer, H., Fundel, F., Ruth, U., Twarloh, B., Littot, G. C., Mulvaney, R., Röthlisberger, R., de Angelis, M., Boutron, C. F., Hansson, M., Jonsell, U., Hutterli, M. A., Lambert, F., Kaufmann, P., Stauffer, B., Stocker, T. F., Steffensen, J. P., Bigler, M., Siggaard-Andersen, M. L., Udisti, R., Becagli, S., Castellano, E., Severi, M., Wagenbach, D., Barbante, C., Gabrielli, P., and Gaspari, V.: Southern Ocean sea-ice extent, productivity and iron flux over the past eight glacial cycles, Nature, 440, 491-496, https://doi.org/10.1038/nature04614, 2006.

Wolff, E. W., Barbante, S., Becagle, S., Bigler, M., Boutron, C. F., Castellano, E., de Angelis, M., and Federer, U.: Changes in environment over the last 800,000 years from chemical analysis of the EPICA Dome C ice core, Quaternary Sci. Rev., 29, 285-295, 2010. 